\title{
IMPACTS OF THE GLOBALISATION ON FREIGHTS IN SHIPPING
}

\author{
VIDUCIC, $\mathrm{V}$.
}

Abstract: Due to the process of globalisation there have been changes in the world trade bearings and forecasts regarding the shipping freights in the future remain uncertain, as there is no period in the recent history of the world that we could use as a comparison or reference point. The globalisation processes have radically changed the situation, fuelling an unprecedented raise of shipping freights. A sharp increase of prices of crude oil and petroleum products will additionally hinder the certainty of freight predictions in times to come. Liquefied gas carriers and container ships have the largest room for growth.

Key words: globalisation, shipping, freights, merchant fleet, world trade
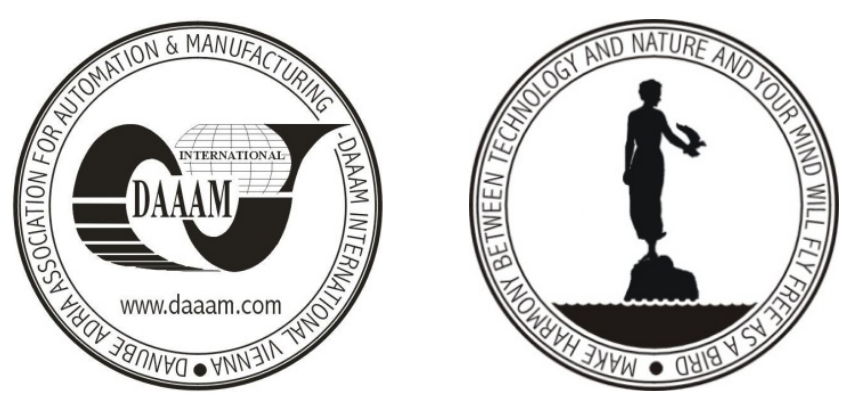

Authors' data: Dr. Viducic, V[inko], Maritime Faculty, Kneza Mislava 6,, 21 000, Podstrana,HR, vviducic@pfst.hr

This Publication has to be referred as: Viducic, V[inko] (2008). Impacts of the Globalisation on Freights in Shipping, Chapter 76 in DAAAM International Scientific Book 2008, pp. 927-934, B. Katalinic (Ed.), Published by DAAAM International, ISBN 978-3-901509-66-7, ISSN 1726-9687, Vienna, Austria DOI: $10.2507 /$ daaam.scibook.2008.76 